\title{
Arrival or Return? Temporality and Materiality of Transit Sites in Overlapping Displacement Context in Border Cities of the Lake Chad Basin Region
}

\author{
Oyewole Simon Oginni ${ }^{1}$ D
}

Accepted: 26 October 2021 / Published online: 5 November 2021

(c) The Author(s) 2021, corrected publication 2022

\begin{abstract}
Since over a decade of conflicts in the Lake Chad Basin region, different measures have been adopted to regulate the mobility of displaced persons in border cities. Mubi-like other transit sites - is both a place of care and control, of incentivization and eviction and of inclusion and exclusion. To nuance these contradictions, I argue that we might have to pay attention to arrival practices in transit sites, particularly the encounter with infrastructures, which are intertwined and profoundly co-constitutive of the displaced persons' realities. In transit sites, arrival is practised and lived temporally and relationally among the displaced persons, despite the conditions of exile and immobility. Urban infrastructures (such as marketplaces, transit camps and living rooms) transform and enact the strategy adopted by the displaced persons to navigate daily life and to 'move on' from conditions of exile and confinement. Moving on, in this sense, is a strategy to overcome the disruption of the temporality of arrival practices from the Nigerian state regulation of mobility through incentivization and encampment policies. I demonstrate that both incentivization and encampment aim towards a common goal, which is to render displaced persons invisible in urban centres while becoming a raw material for capital production. The regulation enables a new form of unplanned spaces to emerge that are hyper-visible and super-precarious at the urban margins. This paper calls for a critical perspective on humanitarian urbanism in the Global South.
\end{abstract}

Keywords Cities · Forced displacement - Internally displaced persons · Lake Chad Basin · Protracted conflicts

Oyewole Simon Oginni

O.oginni@uni-bonn.de

1 Center for Development Research (ZEF), University of Bonn, Bonn, Germany 


\section{Introduction}

The nature, scale and complexity of forced displacement have come under intense scrutiny in the last two decades. This is not unconnected to the increasingly growing population of displaced people globally and the changing character of humanitarian crisis temporally and spatially (Amrith, 2017; Sanyal, 2014b). Between 2010 and 2020, the global displaced population has almost doubled, from 41 million to 79.5 million (UNHCR, 2020). About $85 \%$ of the displaced population is found in the Global South, most of which resides in cities, towns and peri-urban areas or suburbs (Lenner \& Turner, 2019; UNHCR, 2020). It is therefore important to bridge humanitarian and development boundaries in urban areas facing crisis to enable a smooth transition from the preconditions of conflict.

African cities are not an exception to protracted conflicts (Jansen, 2016; Macdonald \& Porter, 2021; L. Pech \& Lakes, 2017). Recently, the border cities in the Lake Chad Basin (LCB) region have become a site of a humanitarian crisis due to a cycle of conflict and fragility (Magrin et al., 2018; Oginni et al., 2020; Ruppel \& Funteh, 2019). The violent conflicts with the non-state armed groups initially started in northeast Nigeria in 2009 but later expanded into Cameroon, Niger and Chad. Since the insurgency, over 4.8 million people have been forcibly displaced from their homes (International Organization for Migration, 2019). In 2016, a Multinational Joint Taskforce was established by the governments of the four countries on a joint counterterrorism operation, which led to the reclaiming of most cities previously controlled by the armed groups in the region (Onapajo \& Ozden, 2020).

After 8 months of the joint counterinsurgency operation, the Nigerian government hastily declared that the armed groups had been "technically defeated" and initiated an agreement with the Cameroon government on the safe return of 260,000 Nigerian refugees in its territory (ICRC, 2018). The internally displaced person (IDP) camps in northeast Nigeria were centralized while the transit sites hosting refugee returnees and IDP returnees in border cities such as the Mubi Burnt Brick Factory (MBBF) camp were shutdown (ICRC, 2016, 2018). However, the hope of surviving the present and navigating an uncertain future oscillates between forced mobility and immobility, conditioned and structured by the institutional forms of power (Brun, 2015; Hänsch, 2020). Most rural parts of the LCB region remain a battlefield, where the armed groups and state military forces test firepower. The armed groups still have some control over territory in rural border communities (Onapajo \& Ozden, 2020). For this reason, there has been a massive influx of displaced populations from borderlines into the border cities in the region.

This paper argues that transit sites are intertwined with, and profoundly coconstitutive of, agentic actions and the displaced persons' realities. I demonstrate this by analysing the conditioning of arrival practices temporarily, but also spatial relations in transit sites in border cities of the LCB region. I particularly focus on the encounter of the displaced people with sociomaterial elements in transit sites, during which they were refugees in Maroua and then refugee returnees and IDP 
returnees in Mubi. Both cities are popular transit sites hosting (un)registered refugees and IDPs in Cameroon and Nigeria, respectively. In doing so, I attempt to show not only what the actors do, think, or act during the encounter (that is, the human agentic action during waiting) in different transit sites, but also 'that what offers them with their actions and intentionality' (Shotter, 2014). I draw attention to the actor-networks influencing arrival practices from the primary point of displacement at the borderlines to their present location in Mubi, Nigeria.

Despite the shift in humanitarian crisis to border cities in the LCB region, to the best of my knowledge, arrival or return practices among refugee and IDP returnees are yet to receive scholarly attention. Attempts to study protracted conflicts in Africa have been made on temporalities of confinement, stuckness and imposed waiting, and how displaced persons exercise political actions as a strategy to navigate everyday life during the waiting period (Jefferson et al., 2019b; Macdonald \& Porter, 2021; Stasik et al., 2020). Central to these previous studies is the view that stuckness does not amount to passivity, and forced mobility creates both opportunities and challenges, depending on how the condition of stuckness is lived, contested and reproduced in everyday life (Jefferson et al., 2019a, 2019b). However, there is an account of an encounter with infrastructures in transit sites and how this transforms and enacts displaced persons' strategy and arrival practices, particularly in the LCB context. This raises questions with respect to what constitutes arrival or return practices in the overlapping displacement context. At what point does (dis)continuity occur in the encounter with material objects of transit sites that create uncertainty or possibilities? What forms of entanglements and political claims the material objects of transit sites enable or upset?

The study approach is grounded in a relational and sociomaterial ontology, in which 'the human and material are an ensemble of continuously performed intrarelations' (Hultin, 2019). In this sense, transit sites and displaced persons, their properties, identities and entities are both the outcome of prior conditions of possibility or uncertainty that bring alive agency and influence in the form that agency can take (Hultin, 2019; Lagesen, 2012; Latour, 2005). The study finds arrival is practised and lived temporally and relationally, despite the experience of exile and immobility. The encounter with urban infrastructures (such as marketplace, transit camps and space of the living room) transforms and animates the strategy to navigate everyday life and to 'move on' from the conditions of stuckness. To move on, in this sense, is not necessarily limited to spatial practice; it is rather a strategy to overcome the disruption of temporality from the Nigerian state regulation of mobility in transit sites through incentivization and encampment policies. The current study contributes to the ongoing debates on humanitarian urbanism, which touches on the intersecting effects of humanitarian actions and urban planning on the long-term stability of cities transiting from protracted conflicts (Jansen, 2018; Potvin, 2013). It highlights urban infrastructures as a critical form of agency that conditions and enacts how displaced persons transit from the pre-condition of conflicts in African cities. 


\section{Arrival Practices in Overlapping Displacement Context in African Cities}

Forced displacement is a new normal that introduces new uncertainties into the lives of people and their relationships with the new environments in which they live (Brun, 2015). As part of arrival practices, new relationships are established with people, technology and entities, or the existing relationships are reassembled anew in the case of IDPs and refugee returnees. New uncertainties are also introduced in the assembling processes of the new relationships in the new environments (Müller, 2015; Nikuze et al., 2019).

In overlapping displacement situation, the relationships between displaced people, the hosts and the sociomaterial elements that form part of the urban space are constantly changing due to the unpredictability of everyday life (Sanyal, 2014a, 2018). In an extreme case, the spaces of arrival and return overlap with each other such that the hosts also become the hosted alongside other internally displaced persons (IDPs) and refugees (Boano \& Astolfo, 2020; Fiddian-Qasmiyeh, 2016). In this vicious cycle of displacement, there are varied forms of uncertainties as the new relationships are established and the old ones are dissolved or reassembled. How do new encounters on arrival introduce uncertainties? At what point do multiple relationships from the encounter stabilize to overcome uncertainties?

African cities are characterized by informality. In the post-conflict context, displaced persons are more likely to be hyper-invisible because the minimum standards for the displaced persons seem to compete and overlap with the urban margins in Africa (Macdonald \& Porter, 2021). This can play a role in the ways the displaced and disempowered transit from the pre-condition of conflicts and how humanitarian actions interact with the dynamics of urbanization processes. As argued by Sanyal (2014a, p. 4), 'the contemporary urban camps for displaced persons do not conform to neat and bounded geographies', rather there is transgression between displaced camps and slums occupied by a large population in the Global South. Sanyal (2014a) observes that overlapping space creates 'political grey spaces' for displaced persons, especially refugees, to engage in different forms of survival in a variety of circumstances.

African post-conflict cities are a site of forced mobility and immobility, conditioned and structured by both informal and formal institutional forms of power. While forced immobility expresses the condition of stuckness in space, forced mobility captures the experience of stuckness in time and space (Jefferson et al., 2019b; Leutloff-Grandits, 2019). The institutional forms of power include camps/ shelters and material interventions, among others, which often serve as an instrument of care and control and inclusion and exclusion (Sanyal, 2017; Stasik et al., 2020). One important point that comes to mind on institutional forms of power is the various ways by which the state exercises control over the mobility of displaced persons in cities, especially how urban spaces are reproduced to keep the unwanted population outside the city view (Potvin, 2013). The other part is the way in which the displaced persons develop resistance in different forms to 
exit and voice and overcome the spatial politics of confinement (Jefferson et al., 2019b; Martin et al., 2020). In both cases, extant studies have reported several attempts of the state to control the visibility of the displaced population in urban centres through political narrative and in connivance with other humanitarian actors to legitimize urban reconstruction projects (Abourahme, 2015; Potvin, 2013).

Regarding the spatial politics in post-conflict cities, Potvin (2013) argues that the modern humanitarian urban practices are more concerned about capital production, which focuses on the well-being of the more privileged than the social survival of the less privileged. Citing the Kabul reconstruction projects in Afghanistan, Potvin (2013) reports that the generous land allocation schemes implemented for the return of the Afghan IDPs and refugees only ensured that they were never allowed into cities because the conditions to receive further assistance was based on their acceptance of living in a rural location. Similarly, Rodgers (2019) offers a critical perspective on the strategies adopted by people in exile to escape from urban confinement. 'Urban confinement constrains the possibility for political actions' (Rodgers, 2019). He argues that confinement can be internalized through escapism, yet the spatial order of things may be unaltered in the process of integration of the spatial status quo through exit, voice and loyalty. Citing types of responses, which led to both real and imaginary mobility, Rodgers (2019:24) demonstrates that response to urban confinement is reflected in 'the terrain of politics in the interaction between agency and space'.

In the recent studies on waiting, stuckness and confinement in Africa, hope, patience and aspiration have been explored from an analytical lens through which the strategy of displaced persons can be understood ( Macdonald \& Porter, 2021; Stasik et al., 2020). Particularly, three fault lines have been in the studies as a frame of analysis with respect to how people develop strategies to navigate urban confinement and temporalities: these include continuity, exclusion/inclusion and hope/abjection (Jefferson et al., 2019a). In terms of continuity, the relationship between sites of confinements is considered as a continuum (Meeus et al., 2018; Stasik et al., 2020). The second fault line is exclusion/inclusion as the ends goals of confinement (Løvgren \& Turner, 2019). The last one focuses on hope, which addresses the choices that people have under extreme circumstances (Hänsch, 2020).

The current study goes further to demonstrate how infrastructures serve as a critical agency that animates and enables the strategy adopted by the displaced persons 'to move on' from the experience of exile and immobility. I trace arrival practices from the primary site of displacement to multiple sites within Mubi Metropolis in northeast Nigeria to capture the continuity and temporality of arrival practices. I investigate the historical processes and materiality of transit sites in Mubi Metropolis and relate them to the Nigerian state control of mobility through incentivization and encampment policies. 


\section{Methodology}

\section{Study Area}

Mubi was the former German Colonial Administrative Quarters that extended to northern Cameroon until it was taken over by the British in 1914 (Mark, 2015; Marc-Antoine Pérouse de Montclos, 2015). As a result of this, the city has maintained close economic and political relations with the major cities in northern Cameroon for several decades (Magrin et al., 2018). Mubi is an old metropolis in northeast Nigeria-well known for its 'welcoming' culture and peaceful cohabitation. The city is approximately $10 \mathrm{~km}$ from the Far North region of Cameroon, and $197 \mathrm{~km}$ southwards is Yola, the capital city of Adamawa state in Nigeria. It is situated on the western flanks of the Mandara Hills from which the Yedseram Rivers flow to other tributaries in the LCB (see Fig. 1).

The larger population of Mubi depends on agriculture for livelihoods: they mainly engage in fishing, crop farming and grazing (Marc-Antoine Pérouse de Montclos, 2015), while others engage in trade and commerce. The prevalent crops farmed include maize, guinea corn, bean, groundnut, cotton, millet, yam and cocoyam. Although the Yedseram River has served the large farming population in Mubi and its neighbouring communities for many years, it has now significantly shrunk alongside the LCB, driving people southward of the city (ICRC, 2018; Nagarajan et al., 2018). Demographically, the city had an estimated population of 281,480 in the last census in 2006, with a young population above $65 \%$ of the total population: $51.5 \%$ of the population is female, while $48.5 \%$ is male with an annual fertility rate of $2.94 \%$ (National Population Commission, 2015). Although Mubi is hailed as one of the cities with the fastest economic growth in Nigeria, the average unemployment rate in Adamawa state is $29.3 \%$, and the underemployment rate is $34.4 \%$, below the national average of $40.8 \%$ (National Bureau of Statistics, 2020). Basic urban services such as clean drinking water, power supply, health services and good road networks are limited. However, the city has a university, polytechnic and college of health and technology and about 43 primary and secondary schools, which draw young people across Nigeria to the city.

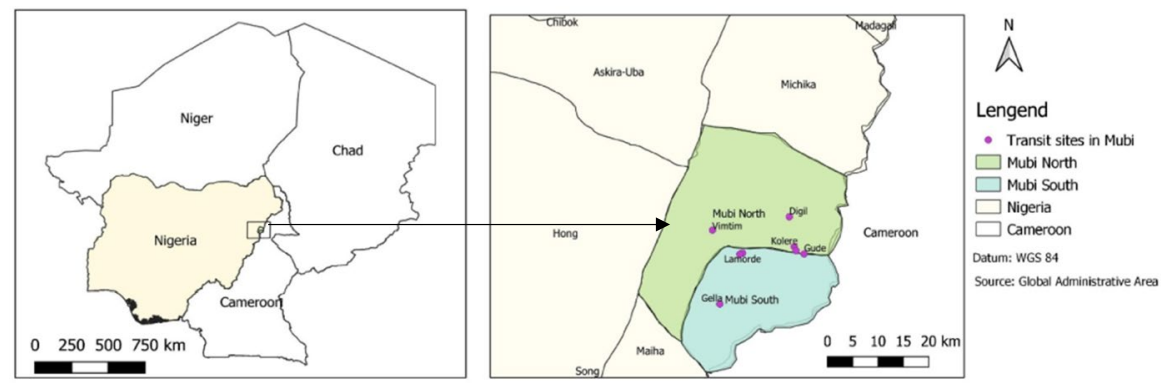

Fig. 1 Map showing Mubi city, northeast Nigeria 


\section{Methods}

The research draws on my 4-year ethnographic study in the LCB region. Specifically, the study was conducted between August 2016 and January 2017 in border cities between Cameroon (Maroua, Mokolo) and Nigeria (Yola, Mubi) and, subsequently, between August 2019 and June 2020 in the major transit sites in Mubi city, northeast Nigeria. The second phase was conducted during my $\mathrm{PhD}$ fieldwork in Mubi. The fieldwork and the data collection methods were approved by the Ethnic Assessment Committee of the University of Bonn, Germany.

To gain insights into transiting sites between the two countries, I observed the routes from Maroua (Cameroon) to Mubi (Nigeria) during the fieldwork. I lived in the informal settlements for 9 months while visiting other settlements in the two cities and border communities. I observed the daily activities that took place in the two major transit sites which hosted displaced persons (mainly IDPs and refugee returnees) and their everyday interactions in the peri-urban Mubi city. At the same time, I explored how the displaced people interacted with the built-in environments of the transit sites (e.g. Mubi beans and cattle markets, Mubi Emir's palace, primary schools, primary healthcare centres and secondary schools). About 30 Mubi natives, 40 IDPs and 35 refugee returnees participated in the study. About $60 \%$ of the participants were women, while $40 \%$ were men. The age range of the participants was 19 to 75 years.

I adopted various interview methods, (non)participatory observations, focused group discussion and transect walk for data collection. The diverse methods and sources allowed for a better understanding of the phenomenon being studied (Carter et al., 2014). The experience of arrival was examined through (a) ethnographic observation and (2) one-on-one interviews and focus group discussions. I conducted interviews with 3 city planners, 15 community leaders, 5 market women and 4 immigration officers to acquire their subjective perspectives on the daily life but also a life with displaced people in the last 4 years.

Refugee returnees were interviewed at different times and locations: the first interview took place when they were refugees in Maroua and Mokolo in Cameroon in 2016 and the second one took place in August 2019 and June 2020 when they returned to Mubi (Nigeria) as refugee returnees. The grassroot organizations supporting displaced women in Cameroon offered insights into the destinations of the former refugees in Nigeria. I conducted 4 focus group discussions (four households in each group) and 19 one-on-one interviews with this group. The participants were asked to trace their experiences from the primary point of displacement to Mubi. They were also asked to elucidate what was their experience on their arrival in Mubi and their relationship with other residents and the environments. 'How would you describe your journey in Mubi so far?' 'What was your experience when you arrived here?' 'What has changed in your daily life since arrival in the city?'.

The data came out in three forms: field notes, interview transcripts and photos. The data collected were all anonymized. The audio-recorded interviews were conducted in five border languages (namely Fulfulde, Fali, Gude, Hausa and Mandara), and the transcripts were validated with the local language experts. A 2-day workshop was held for discussion and reflection on preliminary findings with municipal 
representatives, IDPs leaders and local NGOs in the city. The primary data sources were complemented by grey literatures and archives from public institutions and national dailies.

\section{Arrival of Newcomers: Continuity and Disruption}

Arrival infrastructures can be the material dimension of artefacts such as resident or work permits, camp sites or rented huts or apartments, checkpoints, etc. which shape the arrival experience and condition the mobility within urban spaces. Latham et al. (2014) posit that these varieties of artefacts 'act in distance' through their interconnectedness with other actors, institutions and technologies to shape the 'contemporary experience of temporariness'. In this study, arrival is practised and lived through the multiple relationships that were established with the natives and transit sites while on the move. The study participants, who were refugee returnees, first linked their arrival experience in Mubi to previous encounters at transit points, especially between Cameroon and Nigeria borders. At multiple transit points, the experience of exile and immobility was associated with their inability to access resident and work permits, get registered on mobile telecommunication networks and operate bank accounts as refugees. The relationships formed at each transit point introduced uncertainties that embodied arrival practices in Mubi. Usman and his two wives were among the 35 refugee returnees who shared their arrival experience. I discuss the biographical life of Usman and his family, who had experienced multiple displacements before and after their arrival in Mubi below.

Usman is a 55-year-old farmer from Gzowa, a border town between northeast Nigeria and the Far North region of Cameroon. He was born into a family of 10, and his mother came from Banki (Cameroon), while the father was from Gzowa, Nigeria. Banki (Cameroon) and Gzowa are $\sim 94.7 \mathrm{~km}$ apart. Usman's father was a trader and a farmer. His mother was the second wife; she specialized in handcrafts which she sold at the market in Gzowa. Although Usman acquired skills in handcrafts and transborder trades from his parents, he chose large-scale farming as a profession. Usman finished his junior high school and settled for crop farming. He had an apartment in Gzowa and married two wives with eight children. Many labourers worked on his farm daily.

As conflict ravaged the Gzowa community in early 2014, Usman was one of the IDPs who left his hometown to Maroua in Cameroon. Maroua is about $126.6 \mathrm{~km}$ far from Gzowa. He lived with his family as unregistered refugees for almost 2 years in Maroua. Although two rooms were offered to Usman and his family by the community chief, they did not have a work and resident permit. Only refugees who lived in the camp managed by the UNHCR in the neighbouring community were formally recognized by the Cameroon government (Oginni et al., 2020, 2021). However, Usman's family and many other refugees interviewed were not recognized as an 'ideal' refugee to gain benefits from the government support because they lived in the city [i.e. Maroua] which was about $73 \mathrm{~km}$ away from the UNHCR refugee camp in Mokolo. Thus, they could not engage in any formal income-generating activity that required an identity card or resident permit. Usman lost his identity 
documents to the protracted conflicts in his hometown. He had to work informally on the farmland owned by some Cameroonian natives for a daily wage. Usman was connected to a larger network of the Gzowa community of merchants while working on the farmland. One of the merchants registered him on an Orange mobile network. Usman relied on the mobile network to establish connections to other merchants who facilitated his return to Mubi in Nigeria. Mubi and Maroua are about $195.8 \mathrm{~km}$ apart, with a few villages separating them at the border.

\section{Space of a Living Room: Usman's Arrival in Mubi}

Usman arrived in Mubi with his two wives and eight children, and they all slept in the open field for 3 days. He explained that there was no longer a space to accommodate them in the Mubi Central Mosque which usually hosted IDP and refugee returnees pending transition into the city. Further, Usman narrated that, although it was not easy for his family to sleep in the open field for days, it was far better than the condition of exile and immobility in Maroua (Cameroon).

Usman later secured a single living room through the support of the former IDPs who arrived in Mubi a year earlier. The room was shared by his two wives and four children (below 10 years), and it was about $24 \mathrm{~m}^{2}$ (described with his hands). The other four children (above 15 years) secured a room elsewhere in the city, thanks to a merchant whom Usman met during a Jumaat prayer in Mubi Central Mosque. The main building was built with mud bricks and was covered with iron sheets. Usman narrated that it was the first time his two wives ever lived in a shared single room and that the building looked so unkempt and lacked a proper hygienic convenience room; the toilet was shared among many households in the building. While Usman celebrated his ability to work on farmlands and access basic public services in Mubi, he linked the limited space of his rented living room and lack of privacy to the continuity of the experience of exile and immobility.

\section{Disruption on Arrival: From Housewives to Breadwinners}

The experience of exile and immobility in a living room forced Usman's two wives to step out for a job search at the marketplace to allow their children to sleep conveniently during the day and secure a bigger apartment. They met some market women who shared their experiences about managing daily life as refugee returnees in the city. Halima, the first wife of Usman, narrated that the women they met during their first visit to Tike Central Market advised 'to move on' with any daily job in the market. Both wives secured a cleaning job through the new networks in the market. They earned daily wages that supported the family's daily living expenses. It was the first time they ever worked outside their husband's place of residence. In Gzowa, Usman's hometown, the two wives used to sell food items in front of Usman's apartment, and they often assisted Usman on his farmland during the harvesting period.

It was unconventional for us to go out to the marketplace to engage in a business or work as we do now. He loved that we stay at home, but he also knew what it meant to live in a single room with six people; it was like living in an 
exile as we did in Cameroon where we were immobile (Halima, Usman's first wife).

Usman's wives narrated that the family's economic situation improved since they moved on from being stuck in a living room. It was better off because they were able to contribute to the family's living expenses compared to when they were in Maroua where they lived in a bigger apartment but had no chance of securing any job. Their four children also returned to school. Mubi is a hub for transborder trade within the LCB region and is relatively secure compared to other border cities (Magrin et al., 2018). It has a central market and cattle market. For example, Tike Central Market was initially the third largest cattle market in Nigeria. The cattle market recently emerged as the largest in the country due to the insurgency in other cattle markets in the neighbouring cities. The booming economic activities attracted IDPs from the borderline into the city. Usman's wives were able to secure daily jobs within a short time due to the booming economic activities and the networks he built at the marketplace. They did not need a work permit or national identity card to access a larger marketplace like Tike Central Market in Mubi.

Usman's encounter in a shared living room was his first source of uncertainty on arrival in Mubi but was also a possibility of altered relationships within the household, including the gender roles on a financial contribution to the family upkeeping. The roles that the two wives played in the household changed as soon as they stepped out into the marketplace, which was first superimposed by the continuity of the experience of exile and immobility. Thus, the living single room is an artefact with some inscribed meanings (i.e. signifying being fixed or immobile) that produced surprises and innovation (Xiang \& Lindquist, 2014). It served as a mediator that disrupted the cultural norms that changed the position of the breadwinner in the family. The living room served as a mediator momentarily and disappeared into the background as soon as the roles of the wives and their relationships with other market women took the centre of attention.

Usman's family and many other refugee returnees and IDPs were trapped in a never-ending present, yet they found a possibility to 'move on' as a way of overcoming the conditions of exile and immobility. Thus, a prolonged waiting might suggest passivity, but everyday practices continue as people find alternative futures (Hänsch, 2020; Stasik et al., 2020).

\section{Arrival Practice and Politics of Uncertainty}

Arrival practice expresses the ways in which people resettle and live on a daily basis in a new environment, but also how they are conditioned to act and live in an (un)predictable circumstance (Martin et al., 2020; Meeus et al., 2018). Time is of essence during protracted conflicts because people anticipate the future momentarily due to the uncertainty of the future. In addition, material interventions such as camping sites and relief materials represent an institutional form of power through which future mobilities of displaced persons are negotiated and conditioned (Meeus et al., 2018). The tensions between the lived conditions and strategies to overcome 
future uncertainty make arrival practice temporal, spatial and relational (Hänsch, 2020).

In this section, I show that the Nigerian government regulation of mobility of displaced persons through incentivization and encampment policies enacts how arrival is practised and lived temporarily, spatially and relationally in Mubi metropolis. Nigeria is a signatory to the African Union Convention for the Protection and Assistance of Kampala Convention which extends protections to the IDPs in Africa (African Union, 2009), but its domestication has been problematic at the national level (ICRC, 2018). While the government aims at reducing the number of institutional camps in border cities in Northeast Nigeria, the future lives of the refugee returnees and IDPs are considered less important to the planning process.

In May 2015, a new government was installed in Nigeria. It was a competitive election won on the credentials of a new president who was a retired general in the Nigerian military and believed to have the capability to defeat the insurgency in northeast Nigeria (Marc-Antoine Pérouse de Montclos, 2015; Onapajo \& Ozden, 2020). Six months after counterinsurgency operation in the region, the federal government of Nigeria hastily declared that the armed groups have been 'technically defeated' while asking the IDPs to return to their former homes (Yusuf, 2019). It directed its humanitarian agencies to centralize the IDP camps in northeast Nigeria and shut down the transit sites hosting refugee returnees and IDP returnees in border cities (ICRC, 2016, 2018). Mubi Burnt Brick Factory (MBBF) was one of the largest transit sites in Mubi city that hosted a large population of IDPs and refugee returnees between 2015 and 2016. The period marked the height of overlapping displacement in Mubi in which the existing IDPs and refugee returnees, who already established themselves in the city, were further forcibly displaced along with other natives, following attacks from the insurgents in 2014 (see Fig. 2 for detail).

To implement a camp centralization policy, the Adamawa State Government informed shut down of all the transit camps in Mubi, which included the makeshifts camps in Kolere Primary School and MBBF. Although the action was justified on the need to 'bring together all the IDPs in the state under designated and secured camps' (ICRC, 2016), it was the opposite of the initial political claims over victory

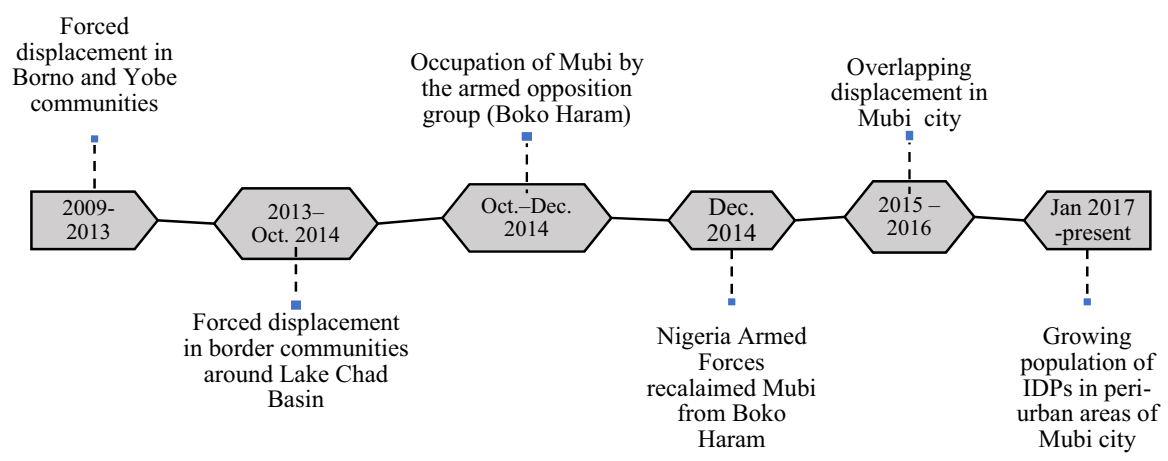

Fig. 2 Diagrammatic illustration showing the historical trajectory of forced displacement in the LCB region 
earlier declared to the public. Most rural parts of the LCB region are still a battlefield where the armed groups and state military forces test firepower. The armed groups still have some control over territory in rural border communities (Onapajo \& Ozden, 2020).

The IDPs and refugee returnees in the camps were offered two options: either to voluntarily leave the camp and to receive a sum of NGN 40,000 (150 Euros) for resettlement in Mubi or to relocate to the centralized IDP camps in the state capital, Yola, which is about $197 \mathrm{~km}$ away. Numerous IDPs were persuaded to take the monetary offer with the promise of transition supports from different humanitarian actors. Both local and international organizations worked with the local governments, local housing agents and religious and traditional rulers to secure accommodation in peri-urban areas of the city due to a higher fee for rent at the central areas. However, the incentive could barely afford a few months of rent in an area with adequate access to basic public services such as healthcare and water supply (Oginni et al., 2021). About 300 IDPs and refugee returnees were relocated from the MBBF camp to the centralized camps in the state capital. The MBBF camp was eventually shut down (ICRC, 2016).

\section{Disruption of Temporality}

Regarding the temporal order, the flow of time transforms and enacts arrival practices (Brun, 2015; Hänsch, 2020; Jefferson et al., 2019b). With the MBBF camp serving as a shelter, the refugee and IDP returnees were able to plan and navigate everyday life in Mubi. Getting familiar with Mubi metropolis and its environments, that is the Central Markets and Beans Markets, was the prevalent practice while still living in the MBBF camps. The practice of place-making is one of the strategies the displaced adopted for reconnaissance and transition from the camp life to urban life. However, the shutdown of transit sites and camps without adequate provisions for housing disrupted the orientation practice, which often took place among the refugee and IDP returnees as informal transiting practice to voluntarily exit from the lives in the MBBF. However, the closure of camping sites re-enacted the experience of exile and immobility among the refugee returnees in Mubi.

I had started rebuilding my life in Mubi before the government asked us to leave the camp. I like the city; I somehow feel attached to the beans market and our big mosque at the centre. I left with my two kids to Yola camp, but I did not see any improvement in my daily life even though it is a bigger city. So, I returned to Mubi to start from zero; it hurts that I am still living as a refugee (Halilu, 27yrs, a refugee returnee)

Orientation is a practice of future-making; it is a strategy to bridge the gap between the present and future during the waiting period (Atkinson, 2018; Brun, 2015). The Nigerian government declaration of victory over the armed groups represents a discursive strategy which was to achieve both political and security goals. While the declaration represents a psychological warfare to boost the morale of the state forces fighting insurgency and regain the public confidence in the state 
capability to defeat the insurgents, it appears to have raised false hope among the displaced persons who were waiting for the crisis to end to move on (Yusuf, 2019). As a result, there was a disruption of arrival practices and strategy towards an alternative future (Brun, 2016; Hänsch, 2020).

\section{Improvised Tactics: Spatial Politics and Practice in Regulated Space}

Regulation of urban space starts with the control of space inhibited by the displaced persons and time spent in shelters or institutional camps. However, since arrival infrastructures are intertwined with agentic actions and profoundly co-constitutive of displaced persons' realities, regulation is constantly challenged through collective and individual actions (Lisa Pech et al., 2018; Sanyal, 2014a). In this sense, displaced people engage in spatial practices, living in-between places, to survive the government policy that regulates their lives. Many IDPs and refugee returnees abandoned the centralized camps in Yola and returned to the former city where they were tactically evicted through 'a safe corridor'. I interviewed about 31 IDPs who returned to Mubi. Zainab, a 37-year-old and an IDP who had to relocate to Digil communities (peri-urban areas of Mubi) following the government incentives, explained how she had changed her identity to benefit from a one-time off supports from the local government.

The natives in Mubi are suffering from the crisis too. So, I often go to my hometown every month to receive humanitarian supports. I registered there as an IDP, and I did the same here too. But there are no longer supports from NGOs. Government usually takes care of the Mubi natives first since IDPs are expected to relocate to Yola camp.

\section{Homogenization of Urban Margin: Exclusion or Inclusion in Transit Sites?}

Due to the linkages of informality and urbanization processes, the minimum standards for the displaced persons compete and overlap with the urban margins in Mubi (Macdonald \& Porter, 2021; Sanyal, 2014a). The challenges of getting to the poor at the urban margins are described by physical distance (that is, remoteness of the location), social distances (poor access to public services and opportunities) and infrastructure deficiency (Von Braun \& Gatzweiler, 2014). Thus, infrastructure has become an institutional form of power employed to isolate the unwanted population in a specific territory (Potvin, 2013; Xiang \& Lindquist, 2014).

The emerging post-conflict cities reflect 'a free-market capture of the urban reconstruction projects which prioritize the aspiration of the local elites' (Potvin, 2013; Rodgers, 2019). Except for the IDP returnees who resettled and lived with their relatives in the city centre as far as 2013, during the early phase of the insurgency in the LCB region, one could only identify displaced persons through their everyday practices in the central markets in Mubi. Abubakar, a 27-year-old refugee returnee, whom I met in the 'Tike Market' explained that many IDPs worked in the market, yet they did not belong to the city. 'We do not belong to the city; you have to 
move far away from the centre to see where belong.' The four humanitarian organizations I interviewed also confirmed Abubakar's lived experience that, although the IDPs were an important raw material for the city's labour market, they were not recognized by the state government as displaced persons after the closure of the transit camps in the city.

I live here just like other residents who need assistance to get back to life. So, we can hardly be differentiated from each other until we can find out how we differ in terms of privileges they have over us. (Ahmed, a 25-year-old male IDP returnee)

In Mubi, many refugee returnees and IDPs lived in red-brick houses outside the view of the city. They rented the red-brick apartments from the Mubi natives who also lived in the neighbourhood. Although Mubi natives and the IDPs who lived in urban margins could hardly be differentiated from each other due to shared socioeconomic conditions, they were different in terms of privilege and rights of access to public services. Both Mubi natives and the refugee returnees could be described as the urban poor, but the IDPs and refugee returnees could be described as 'the poorest of the urban poor'. The Mubi local government urban planners were worried about the conditions of infrastructure in urban neighbourhoods occupied by refugee returnees and IDPs. Three new neighbourhood communities are identified as unplanned and vulnerable.

The red-brick houses are not in our city plan. The houses in the new neighbourhood were built without approval from the local government. The new Digil communities, for example, have no clean water, power supply and good road networks. Some houses were built on the main road (Mubi Municipal official 1, 56 yrs)

\section{Zooming into Access and Privilege in Homogenized Urban Margin}

Nigeria operates a three-tier government: the local government area (LGA) is the third tier. A certificate is issued to indigene-settlers as a proof of belonging to a community, ethnic group or a LGA (Adesoji \& Alao, 2009). The indigene-settlers who have this certificate or can demonstrate to have married a partner from the area or can demonstrate that they are children of parents who hold the certificate enjoy some privileges. A female refugee returnee narrated that her children benefited from educational supports because her husband was an indigene-settler in Adamawa state. However, many refugee returnees' children whose parents had a different state of origin needed an approval from a local or state education board to benefit from educational support such as payment of terminal examination at the secondary school level.

I must assess the situation of returnees' children on a case-by-case basis. I must find out if they commenced their education in the French System, or not, and test their knowledge in English. In addition, we must check whether their parents are from Adamawa State or not. In some cases, I accept them 
into our schools, or I refer them to the state education board for approval (A school principal in Mubi, 57 yrs)

In this section, I have shown that arrival practices in transit sites are conditioned and structured by institutional forms of power. Foucault describes the strategy adopted by the state to regulate the mobility of people in confinement as improvised tactics, arguing that it is 'thoroughly heterogeneous ensembles that comprise different elements, the said and the unsaid and the system of relations that can be established between these elements' (Foucault, 1980, p. 184). Oesch (2020: 353) further elaborates that such tactics can be heterogeneous elements such 'urban practices, discourses and institutions' that appear to be unconnected at the first instance as they would be in an inclusive plan.

The centralization of camps and incentivization of displaced persons in transit sites embody care and control, but also an improvization that shapes arrival practices within the Mubi metropolis. Both incentivization and encampment policies are targeted towards a common goal to make the displaced persons invisible in border cities such that they become indistinguishable from other marginalized groups whose socioeconomic characteristics overlap at the margin of the city. This resonates Oesch's (2020) argument that the state often improvises incoherent urban planning policies to achieve 'a material homogenization between the camp and surrounding urban space.'

Despite the overwhelming evidence of overlapping displacement in Mubi, what motivated the premature shutdown of the MBBF (transit) camp? For whom and whose interests? What forms of entanglements and political claims did the $\mathrm{MBBF}$ enable or upset? In the next section, I describe and analyse the material objects of the MBBF camp as well as its actor-networks.
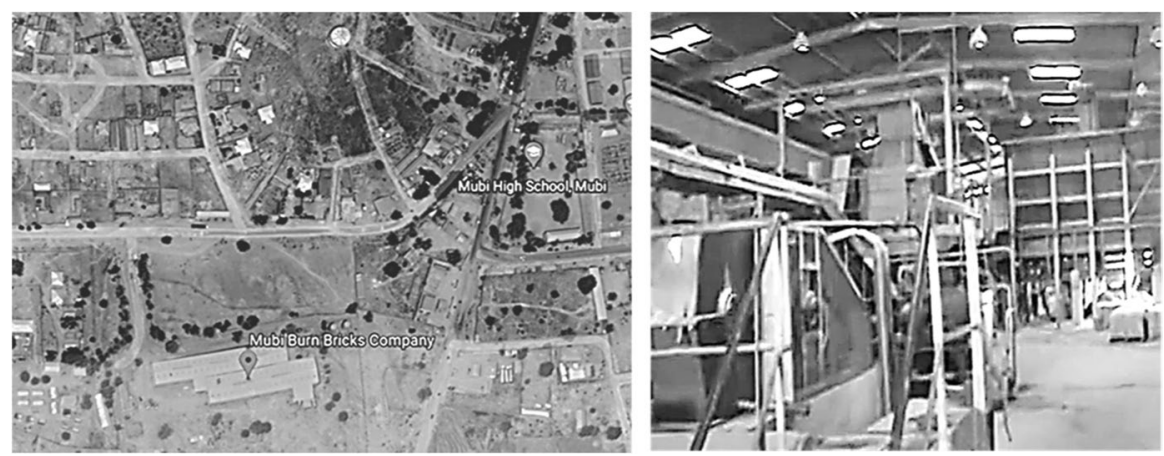

Fig. 3 Photo showing MBBF, northeast Nigeria 


\section{Materiality of Transit Sites: MBBF}

MBBF was established in the 1980s. It was born out of the national industrial development programmes in Nigeria. The factory produced burnt bricks of various sizes such as facing slips, decking materials, walls and facing bricks (see Fig. 3). Thus, it was the biggest factory in the entire northern Nigeria between the 1980s and 1990s. The proximity to raw materials explained why the factory was set up at the entrance of the city. Formerly, the vast landmass was a motor park for transporting goods and people between Cameroon and Nigeria. The strategic location of the factory placed it above its counterparts established across the country.

However, MBBF was forced to shut down because it could not break even. The high cost of maintenance of the equipment and poor management led to its demise. Other sister industries which depended on the operation of the factory for survival were affected. However, the factory was resuscitated in 2006 for the construction of the Yola modern market. It functioned for a year and then ceased to operate.

Amidst the overlapping displacement, the state government made a case for the factory to be re-opened for industrial production. Experts assessed the mineral deposits in the city (Martins \& Gadiga, 2015). The state government assured the public that the factory could create about 125,000 jobs and that the IDPs were better secured at the centralized camps in the state capital. The idea that the factory would create jobs was appealing to the natives of the city. Although the MBBF, being operated as a transit camp, attracted humanitarian organizations that created some jobs and relief supports to the host communities, it was not enough to convince the large population of unemployed youth in the city.

Although the MBBF camp was shut down with the goal of reviving industrial production in the factory, at the time of writing this paper, the factory has not served this purpose. Hence, no job has been created. The city continues to attract a huge population of IDPs from neighbouring border communities due to the booming economic activities and for the fact that many rural parts of the LCB are a battlefield for the exchange of firepower between the insurgents and the Nigerian state force. Public services such as healthcare and schools have been overstretched in the city (Author et al., 2021).

I think we may be double or triple by now, perhaps around 500,000 people live in Mubi compared to about 286,000 in 2006. Before now, we were used to having 30 pupils in a class, but now we are having 90 people with a teacher. (A retired immigration officer narrated, age $65 \mathrm{yrs}$ )

\section{'Everyone Wants the Factory Back': Solidarity of Actor-Networks}

According to Latour (2005: 70), specific tricks must be developed to make objects to talk 'to offer descriptions of themselves, to produce scripts of what they are making others - humans or non-humans-do.' The MBBF transit site does not just remain mute, the large deposit of clays, different forms of rocks (syntactonic granites, gneisses, and alluvium), gravelly sands, muds, ironstones, etc. go into the processes 
of their assemblage as the burnt brick factory to facilitate the closure of the camps. The clays are transformed by the machines and factory workers into burnt bricks. However, in the process of extracting the clays, rocks, gravel and ironstones are also excavated, which become another source of raw materials/products to the allied companies such as ceramic production firms. Looking at the forms of political claims that MBBF enables, the factory, in and of itself, also played an intermediary role in connecting different actors and interests.

Mubi and its surroundings have extensive deposits of clay that are fine-grained, moderately dense and plastic, and approximately 12,712 ha or more (Ntekim, 2003). These clays are bounded by different forms of rocks (including the syntectonic granites, gneisses and alluvium), and they occur in association with gravelly sands, muds and ironstones (Martins \& Gadiga, 2015). This provides for a diverse source of usage and income-generating activities such as ceramic production, gravel and sand for building constructions. The existence of the allied clay companies depends largely on the operation of the MBBF. Quarry companies are also situated behind the factory. The Mubi natives, especially from the Vimtim settlement, engage in small-scale pottery production such as that of traditional pots and kitchen utensils with clays. Vimtim is a settlement with about $3 \mathrm{~km}^{2}$ of clay deposits, from which the Mubi Burn Bricks Factory sources its raw materials.

Different interests are generated from the production cycle of the burnt bricks; the different actors and interests played roles that legitimized the closure of the transit camps in favour of industrial production. MBBF is located at the checkpoints, in which different border security agencies generated both legal and illegal incomes from transborder traders. 'I think the presence of IDPs, and humanitarian agencies obstructed the income generating activities at the checkpoints', narrated a resident formerly working in the transit camp. The collective acceptance of the shutdown proposal from the stakeholders represents a source of legitimacy for the state government. As noted by a state university lecturer who I interviewed in a restaurant at the city's centre, 'everyone wants the factory back. So, it does not matter if the IDPs live there or not; it is about the economy of the city'.

\section{Conclusion}

After over a decade of conflicts and fragility in the LCB region, different measures have been adopted to maintain order and regulate the mobility of displaced persons in cities at the borderlines. Since 2015, different mechanisms have been adopted on spatial distribution and camping of a significant number of the IDPs and refugee returnees in Mubi. The urgent need to secure the city by ensuring temporal characters of transiting sites in Mubi Metropolis created uncertainties but also opportunities that shape arrival practices temporarily, relationally and spatially.

Although the MBBF camp was closed, and the displaced population was relocated $197 \mathrm{~km}$ away from the city, the numbers of the IDPs residing in the peri-urban areas have doubled in the last 2 years (ICRC, 2016). The displaced who were resettled elsewhere outside the city returned to the city, adding to a significant number of the IDPs living in peri-urban areas of the city. The absence of transit camps and 
makeshifts rendered the process of integration of the IDPs and refugee returnees very difficult because the minimum standards for the displaced persons compete and overlap with the urban margins.

As suggested by Potvin (2013), humanitarian actors are yet to grasp the dynamic of urbanization processes, and when they are allowed to take charge within urban space, they often circumscribe sites of intervention in a way that promotes the privileged over the less privileged within the urban space. Displaced persons in Mubi relied on the promise of support from the humanitarian agencies as a condition to relocate from the MBBF. However, the absence of institutional humanitarian camps led to the low presence of humanitarian actors, both local and international actors, that could have facilitated a faster integration and livelihood recovery. In this study, I have demonstrated how the co-optation and complex institutional arrangements on access to specific urban services led to the disruption of arrival practices and promoted exclusion in peri-urban areas of the city.

The Nigerian government's attempt to control the mobility of displaced persons in border cities has both intentional and unintentional consequences. The intentional outcome ensures the invisibility of the displaced persons in the central area of Mubi. This was made alive through its incentivization and encampment policies which failed to address the emergence of the unplanned spaces that are hyper-visible and super-precarious at the urban margins in Mubi. Yet, displaced persons have become an important raw material for capital production in the city's market centre.

As demonstrated in this study and elsewhere, the emerging post-conflict cities reflect capitalist capture of urban reconstruction project which prioritizes the aspirations of the local elites (Potvin, 2013; Rodgers, 2019). The profound interlinkages of urban development and informality in African cities call for inclusive urban policies. Such urban policies should be aimed at bridging humanitarian and urban development gaps, and should involve all actors, including the displaced and disempowered, who should not be the object of interventions of others. In the case of Mubi, the humanitarian interventions reduced the moment the state government shutdown institutional camps, even though there was a huge humanitarian crisis in the city. Humanitarian organizations moved to a new area outside the city where they had more visibility and control over the institutional camps. This raises the question as to whether humanitarian institutions are well-equipped to tackle the complex urbanization processes, but also if they can remain apolitical and non-profit seeking in urban space where the politics of place and space play significant roles in urban reconstruction processes (Feldman, 2014).

A starting point is to recognize infrastructure not only as the outcome of a possibility, but also as a critical form of agency that enables the people living in crisis to transit from the preconditions of conflicts. 'Humanizing urbanism' is a goal that goes beyond 'camp approach', which humanitarian organizations have micromanaged over the years. Slightly different from the call for understanding how camps become urbanized (Jansen, 2018; Sanyal, 2014b), we should perhaps look at how urban become human enclaves and asylums for the displaced and disempowered. This is a call for 'critical humanitarian urbanism', in which urban reconstruction after protracted conflicts is not defined by urban modernity (that is the neoliberal ideal of what a city should be), but the embedded historical processes and 
peculiarity of cities in Africa. Perhaps, this requires identifying the place of history and urban identities and their planetary links to the urbanization processes, but also the links of informality and forced displacement to urban stability.

\section{Author Contribution NA.}

Funding Open Access funding enabled and organized by Projekt DEAL. The fieldwork for this research was funded by the Federal Ministry of Economic Cooperation and Development (BMZ) via Deutscher Akademischer Austauschdienst (DAAD) [Grant number: 4/01271].

Data Availability Audio-recorded interviews are available in six border languages. However, given the sensitive nature of the interviews and privacy concern, audio records are not available to the third party. Anonymized transcripts are available on request. The approved interview guide used for the paper is also available on request.

\section{Code Availability NA.}

\section{Declarations}

\section{Ethics Approval NA}

\section{Consent to Participate NA}

\section{Consent for Publication NA}

Conflict of Interest The author declares no competing interests.

Open Access This article is licensed under a Creative Commons Attribution 4.0 International License, which permits use, sharing, adaptation, distribution and reproduction in any medium or format, as long as you give appropriate credit to the original author(s) and the source, provide a link to the Creative Commons licence, and indicate if changes were made. The images or other third party material in this article are included in the article's Creative Commons licence, unless indicated otherwise in a credit line to the material. If material is not included in the article's Creative Commons licence and your intended use is not permitted by statutory regulation or exceeds the permitted use, you will need to obtain permission directly from the copyright holder. To view a copy of this licence, visit http://creativecommons.org/licen ses/by/4.0/.

\section{References}

Abourahme, N. (2015). Assembling and spilling-over: Towards an "ethnography of cement" in a Palestinian refugee camp. International Journal of Urban and Regional Research, 39(2), 200-217. https:// doi.org/10.1111/1468-2427.12155

Adesoji, A., \& Alao, A. (2009). Indigeneship and citizenship in Nigeria: Myth and reality. The Journal of Pan African Studies (online), 2(9), 151.

African Union. (2009). Kampala Convention: African Union Convention for the Protection and Assistance of Internally Displaced Persons in Africa. https://au.int/sites/default/files/treaties/36846treaty-kampala_convention.pdf. Accessed 20 Dec 2020

Amrith, M. (2017). Cities as humanitarian actors in contexts of displacement (04/02). https://i.unu.edu/ media/gcm.unu.edu/publication/3521/REPORT-0402.pdf. Accessed 20 Dec 2020

Atkinson, W. (2018). Time for Bourdieu: Insights and oversights. Time \& Society, O(0). https://doi.org/10. $1177 / 0961463 X 17752280$ 
Boano, C., \& Astolfo, G. (2020). Notes around hospitality as inhabitation engaging with the politics of care and refugees' dwelling practices in the Italian urban context. Migration and Society: Advances in Research, 3(2), 222-232. https://doi.org/10.3167/arms.2020.0

Brun, C. (2015). Active waiting and changing hopes: Toward a time perspective on protracted displacement. Social Analysis, 59(1), 19-37. https://doi.org/10.3167/sa.2015.590102

Brun, C. (2016). There is no future in humanitarianism: Emergency, temporality and protracted displacement. History and Anthropology, 27(4), 393-410. https://doi.org/10.1080/02757206.2016.1207637

Carter, N., Bryant-Lukosius, D., DiCenso, A., Blythe, J., \& Neville, A. J. (2014). The use of triangulation in qualitative research. Oncology Nursing Forum, 41(5), 545-547. https://doi.org/10.1188/14.ONF. 545-547

Feldman, I. (2014). What is a camp? Legitimate refugee lives in spaces of long-term displacement. Geoforum, 66, 244-252. https://doi.org/10.1016/j.geoforum.2014.11.014

Fiddian-Qasmiyeh, E. (2016). Repressentations of displacement from the middle east and North Africa. Public Culture, 28(3), 457-473. https://doi.org/10.1215/08992363-3511586

Foucault, M. (1980) The confession of the flesh. In C. Gordon (Ed.), Power/knowledge: selected interviews and other writings. Harvester Press.

Hänsch, V. (2020). On patience: Perseverance and imposed waiting during dam-induced displacement in Northern Sudan. Critical African Studies, 12(1), 79-92. https://doi.org/10.1080/21681392.2019. 1697317

Hultin, L. (2019). On becoming a sociomaterial researcher: Exploring epistemological practices grounded in a relational, performative ontology. Information and Organization, 29(2), 91-104. https://doi.org/ 10.1016/j.infoandorg.2019.04.004

ICRC. (2016). Internal displacement in north-east Nigeria: Operationalising the Kampala convention in Borno, Adamawa and Yobe states. https://www.globalprotectioncluster.org/_assets/files/tools_and_ guidance/InternalDisplacement/internal-displacement-in-north-east-nigeria.pdf. Accessed 20 Dec 2020

ICRC. (2018). Displaced in cities. https://shop.icrc.org/displaced-in-cities-experiencing-and-respondingto-urban-internal-displacement-outside-camps-2822.html?__store=default. Accessed 20 Dec 2020

International Organization for Migration. (2019). Emergency tracking tool (Ett). https://displacement. iom.int/system/tdf/reports/IOM Nigeria DTM Emergency Tracking Tool \%28ETT\%29 Report No.112 \%2825 - 31 March 2019\%29_0.pdf?file=1\&type=node\&id=5423

Jansen, B. J. (2016). The protracted refugee camp and the consolidation of a humanitarian urbanism. International Journal of Urban and Regional Research. https://library.wur.nl/WebQuery/wurpubs/ fulltext/419236. Accessed 20 Dec 2020

Jansen, B. J. (2018). Kakuma refugee camp: Humanitarian urbanism in Kenya's accidental city. Zed Books Ltd. https://doi.org/10.5040/9781350220942

Jefferson, A., Turner, S., \& Jensen, S. (2019a). Introduction: On stuckness and sites of confinement introduction: On stuckness and sites of confinement. 1844. https://doi.org/10.1080/00141844.2018.15449 17

Jefferson, A., Turner, S., \& Jensen, S. (2019b). Introduction: On stuckness and sites of confinement. Ethnos, 84(1), 1-13. https://doi.org/10.1080/00141844.2018.1544917

Lagesen, V. A. (2012). Reassembling gender: Actor-network theory (ANT) and the making of the technology in gender. https://doi.org/10.1177/0306312712437078

Latham, R., Vosko, L. F., Preston, V., \& Melisa, B. (2014). Liberating temporariness? (L. F. Vosko, V. Preston, \& R. Latham (eds.)). McGill-Queen's University Press. http://www.jstor.org/stable/j.ctt7z t1sf. Accessed 20 Dec 2020

Latour, B. (2005). Reassembling the social: An introduction to actor-network-theory. In Science \& Technology Studies. Oxford University Press. https://doi.org/10.23987/sts.55207

Lenner, K., \& Turner, L. (2019). Making refugees work? The politics of integrating Syrian tefugees into the labor market in Jordan. Middle East Critique, 28(1), 65-95. https://doi.org/10.1080/19436149. 2018.1462601

Leutloff-Grandits, C. (2019). Temporalities of refugee experience in Germany. Diversification of asylum rights and proliferation of internal boundaries Le temporalità dell'esperienza di rifugiato in Germania. Diversificazione del diritto d'asilo e proliferazione dei confini interni. Archivio Antropologico Mediterraneo, 21(2), 0-17. https://doi.org/10.4000/aam.2432

Løvgren, R., \& Turner, S. (2019). 'Winning life' and the discipline of death at Iwawa Island. Ethnos, 84(1), 27-40. https://doi.org/10.1080/00141844.2017.1373687 
Macdonald, A., \& Porter, H. (2021). The politics of return: Understanding trajectories of displacement and the complex dynamics of 'return' in Central and East Africa. Journal of Refugee Studies, 33(4), 639-662. https://doi.org/10.1093/jrs/feaa118

Magrin, G., Montclos, M. P. De, Chauvin, E., Lemoalle, J., Raimond, C., Rangé, C., Doua, S. A., Dangbet, Z., Don-donné, G. P., Hessana, A., Higazi, A., Fougou, H. K., Mahamadou, A., Mohamed, K., Tafida, A. A., Tukur, A. L., \& Zieba, F. W. (2018). Crisis and development the Lake Chad region and Boko Haram. http://www.jstor.org/stable/j.ctt7zt1sf. Accessed 20 Dec 2020

Mark, B. F. (2015). The paradox of Cameroon-Nigeria interactions: Connecting between the edges of opportunity/benefit and quandary. International Journal of Peace and Development Studies, 6(3), 30-48. https://doi.org/10.5897/IJPDS2015.0224

Martin, D., Minca, C., \& Katz, I. (2020). Rethinking the camp: On spatial technologies of power and resistance. Progress in Human Geography, 44(4), 743-768. https://doi.org/10.1177/0309132519 856702

Martins, A. K., \& Gadiga, B. L. (2015). Satellite remote sensing for mineral deposit assessment of clay in Mubi Local Government Area of Adamawa State, Nigeria. Geoscience, 5(1), 26-30. https://doi.org/10.5923/j.geo.20150501.03

Meeus, B., Van Heur, B., \& Arnaut, K. (2018). Migration and the infrastructural politics of urban arrival. In Arrival Infrastructures: Migration and Urban Social Mobilities. https://doi.org/10. 1007/978-3-319-91167-0_1

Montclos, Marc-Antoine Pérouse de. (2015). Boko Haram: Islamism, politics, security and the state in Nigeria. In Marc-Antoine P. de Montclos (Ed.), African Security Review (Vol. 24, Issue 1). African Studies Centre. https://doi.org/10.1080/10246029.2015.996023

Müller, M. (2015). Assemblages and actor-networks: Rethinking socio-material power, politics and space. Geography Compass, 9(1), 27-41. https://doi.org/10.1111/gec3.12192

Nagarajan, C., Pohl, B., Rüttinger, L., Sylvestre, F., Vivekananda, J., Wall, M., \& Wolfmaier, S. (2018). Climate-fragility profile: Lake Chad Basin. https://www.adelphi.de/en/publication/clima te-fragility-profile-lake-chad-basin. Accessed 20 Dec 2020

National Bureau of Statistics. (2020). Labor force statistics: Unemployment and underemployment report. Labor Force Statistics Unemployment and Underemployment Report, 1(December), 1-88. https://www.proshareng.com/news/NigeriaEconomy/Unemployment-Rate-Rises-to-18.8Percenti/37757. Accessed 20 Dec 2020

National Population Commission. (2015). RAPID: The change we seek raising our quality of life. file://C:/Users/USER/Desktop/RAPID ADAMAWA STATE NIGERIA.pdf

Nikuze, A., Sliuzas, R., Flacke, J., \& van Maarseveen, M. (2019). Livelihood impacts of displacement and resettlement on informal households - A case study from Kigali, Rwanda. Habitat International, 86(February), 38-47. https://doi.org/10.1016/j.habitatint.2019.02.006

Ntekim, E. E. (2003). Ceramic qualitites of Instustiral clay deposites at Vimim in Mubi, Northeastern Nigeria. Global Journal of Geological Sciences, 1(1), 169-177.

Oginni, S. O., Opoku, M. P., \& Alupo, B. A. (2020). Terrorism in the Lake Chad region: Integration of refugees and internally displaced persons. Journal of Borderlands Studies, 35(5), 725-741. https://doi.org/10.1080/08865655.2018.1457975

Oesch, L. (2020). An improvised dispositif: Invisible urban planning in the refugee camp. International Journal of Urban and Regional Research, 44(2), 349-365. https://doi.org/10.1111/14682427.12867

Oginni, S. O., Opoku, M. P., \& Nketsia, W. (2021). Crisis at the intersection of four countries: Healthcare access for displaced persons in the Lake Chad Basin region. Ethnicity \& Health, O(0), 1-20. https://doi.org/10.1080/13557858.2021.1947471

Onapajo, H., \& Ozden, K. (2020). Non-military approach against terrorism in Nigeria: Deradicalization strategies and challenges in countering Boko Haram. Security Journal, 33(3), 476-492. https://doi.org/10.1057/s41284-020-00238-2

Pech, L., \& Lakes, T. (2017). The impact of armed conflict and forced migration on urban expansion in Goma: Introduction to a simple method of satellite-imagery analysis as a complement to field research. Applied Geography, 88, 161-173. https://doi.org/10.1016/j.apgeog.2017.07.008

Pech, Lisa, Büscher, K., \& Lakes, T. (2018). Intraurban development in a city under protracted armed conflict: Patterns and actors in Goma, DR Congo. Political Geography, 66(October 2017), 98-112. https://doi.org/10.1016/j.polgeo.2018.08.006

Potvin, M. (2013). Humanitarian urbanism under a neoliberal regime. International RC21 Conference 2013, August. 
Rodgers, D. (2019). Urban anti-politics and the enigma of revolt: Confinement, segregation, and (the lack of) political action in Contemporary Nicaragua. Ethnos, 84(1), 56-73. https://doi.org/10. 1080/00141844.2018.1454487

Ruppel, O. C., \& Funteh, M. B. (2019). Chapter 5: Climate change, human security and the humanitarian crisis in the Lake Chad Basin region: Selected legal and developmental aspects with a special focus on water governance. In Law | Environment | Africa (Issue 2016). https://doi.org/ $10.5771 / 9783845294605-105$

Sanyal, R. (2014a). Urbanizing refuge: Interrogating spaces of displacement. International Journal of Urban and Regional Research, 38(2), 558-572. https://doi.org/10.1111/1468-2427.12020

Sanyal, R. (2014b). From camps to urban refugees: Reflections on research agendas. International Journal on Urban and Regional Research.

Sanyal, R. (2017). A no-camp policy: Interrogating informal settlements in Lebanon. Geoforum, 84(April), 117-125. https://doi.org/10.1016/j.geoforum.2017.06.011

Sanyal, R. (2018). Managing through ad hoc measures: Syrian refugees and the politics of waiting in Lebanon. Political Geography, 66(June 2016), 67-75. https://doi.org/10.1016/j.polgeo.2018.08.015

Shotter, J. (2014). Agential realism, social constructionism, and our living relations to our surroundings: Sensing similarities rather than seeing patterns. Theory \& Psychology, 24(3), 305-325. https://doi. org/10.1177/0959354313514144

Stasik, M., Hänsch, V., Mains, D., \& Stasik, M. (2020). Temporalities of waiting in Africa. 1392. https:// doi.org/10.1080/21681392.2020.1717361

UNHCR. (2020). Trends at a glance: Global trends forced displacement in 2019. In UNHCR The UN Refugee Agency. https://www.adelphi.de/en/publication/climate-fragility-profile-lake-chadbasin. Accessed 20 Dec 2020

Von Braun, J., \& Gatzweiler, F. W. (2014). Marginality-A framework for analyzing causal complexities of poverty. In Marginality: Addressing the nexus of poverty, exclusion and ecology. https://doi.org/ 10.1007/978-94-007-7061-4

Xiang, B., \& Lindquist, J. (2014). Migration infrastructure. International Migration Review, 48(1_suppl), 122-148. https://doi.org/10.1111/imre.12141

Yusuf, I. U. (2019). Countering Boko Haram insurgency and terrorism: Assessment of media campaigns. Global Media Journal, 17(32), 1-11.

Publisher's Note Springer Nature remains neutral with regard to jurisdictional claims in published maps and institutional affiliations. 